\title{
The Transfer of Knowledge between Younger and Older Employees in the Health and Medical Care: An Intervention Study
}

\author{
Emma Nilsson ${ }^{1}$, Kerstin Nilsson ${ }^{1,2 *}$ \\ ${ }^{1}$ Division of Occupational and Environmental Medicine, Lund University, Lund, Sweden \\ ${ }^{2}$ Department of Work Science, Business Economics \& Environmental Psychology, Swedish University of Agricultural Sciences, \\ Alnarp, Sweden \\ Email: *kerstin.nilsson@med.lu.se, *swage.research@gmail.com
}

How to cite this paper: Nilsson, E. and Nilsson, K. (2017) The Transfer of Knowledge between Younger and Older Employees in the Health and Medical Care: An Intervention Study. Open Journal of Social Sciences, 5, 71-96.

https://doi.org/10.4236/jss.2017.57006

Received: May 10, 2017

Accepted: July 9, 2017

Published: July 12, 2017

Copyright $\odot 2017$ by authors and Scientific Research Publishing Inc. This work is licensed under the Creative Commons Attribution International License (CC BY 4.0).

http://creativecommons.org/licenses/by/4.0/

\begin{abstract}
In the ageing society more old employees need to stay in working life for longer. However, the society also needs to take care of the increased amount of elderly in a more effective and respectful way. To take care of older employees experience knowledge to make the elderly care and the care employees work situation better and self-crediting to go on in an extended working life, new methods and measures are needed to be developed and evaluated. The overall purpose of this article was to evaluate how the participant in the intervention project experienced the project and its methodology. The intervention project followed three different methods: i) through interviews of the participants and the supervisor; ii) through participant observation; and iii) through an evaluation questionnaire to participants after the project was completed. The intervention project did transfer knowledge between different fields, that are, between generations, between different departments and between the municipality and county. The participation was described as not only a place for reflection and knowledge, but also a protected zone where participants could talk about the kind of problems they would ponder over. Several participants felt that it was important to develop and continue the work that the intervention project set in motion. The participants' experience was made to be visible and their professional competence has been strengthened. They indicated that there had been an exchange of knowledge and between not only the generations but also the different kinds of work. The organisations also seem to have gained from the project by allowing the participants to unload, become more positive, develop more knowledge of experience, increase their propensity for reflection and get a better consensus between the municipality and county. The intervention project seems to have fulfilled the stated purpose and also the expectations of the participants.
\end{abstract}




\section{Keywords}

Elderly, Work Environment, Intervention, Knowledge, Experience, Health and Medical Care, Occupational Health, Older Worker, Management, Public Health

\section{Introduction}

The population is ageing and the proportion of older workers in employment is increasing [1] [2] [3]. The demographic shift brings challenges and opportunities for societies and requires the implementation of policies to help people stay healthy and active in old age, as well as on ageing in working life. At the societies macro level the interest is on how to take care of the elderly in a proper way, and how to endorse more people to stay in work to maintain the welfare system in a sustainable economic approach and to transfer their experience knowledge to younger generations [4]. However, the meso level is an important level for sustainable measures and strategies to make an extended working life possible [5]. At the micro level, older workers have a different agenda. People considering own retirement in association to stay in work for some more years. There are nine different areas that effect work life participation [6] [7]: health, physical work environment, mental work environment, work scheme and work pace, knowledge and skills, work satisfaction, managers' attitudes and discrimination, partner and family situation, private economic. The older workers retirement decisions are based on considerations of [6] [8]:1) their health in relation to the work situation and work environment versus health as retired;2) their personal economic situation in employment versus in retirement; 3) the opportunities for social inclusion in working life situations versus as a retired; 4) and the opportunities for meaningful and self-crediting activities in working life versus in retirement. At the meso level, i.e. organisation level, productivity is the most important. The organisation needs to take care of the older workers experience knowledge from a long working life to keep and transfer the knowledge capital to the younger and new employees. However, the organisations had also to go on and offer possibilities to development and new knowledge to older employees or else they could feel discredited and leave for retirement [6] [7] [8] [9].

The experience an individual has accumulated over a long working life is an important capital for the organisation that should be taken advantage of. It is often regarded as vital to any organisation's survival to nurture human capital, i.e. staff competence, efficiency and capacity [10] [11]. Employees feeing value for their knowledge and having controlled over their work situation provide a great positive impact on mental and social wellbeing which persists after retirement [6] [12] [13]. At the same time an organisation that invests in their employees and creates work environments where collaboration and ideas are encouraged has proven to be significantly more effective [11].

In the ageing society more older employees need to stay in working life for 
longer. However, the society also need to take care of the increased amount of elderly in a more effective and respectful way. How to make the work situation more sustainable and increase the possibilities to take care of and transfer the older employees experience knowledge is important when the populations are ageing and a great part of the population soon will leave the organisations and enterprises for retirement. To take care of older employees experience knowledge to make the elderly care and the care employees work situation better and self-crediting to go on in an extended working life new methods and measures is needed to be developed and evaluated. A searching for scientific papers shows only some proceedings on the subject transfer of knowledge between younger and older employees from year 2000-2016 in the database Pub Med and Scopus [14] [15]. A recent review study also described the lack of scientific published evaluations of intervention projects including older employees [16]. More knowledge of intervention design and evaluation methods of intervention project is requested.

Objectives. The overall purpose of this article was to evaluate how the participants in an intervention project experienced the project and its methodology. The study includes a descriptive process evaluation of an intervention project of the transfer of knowledge between younger and older employees in the healthand medical care. It purposes how the participants and the supervisor experienced the project. The research questions were: Did the participants experience that their knowledge of experience has been made visible and their professional competence has been strengthened? Did the participants experience that there has been an exchange of knowledge between generations? Did the participants experience that the intervention project has developed in their professional capacity? How did the participants experience the fact that the groups have been mixed and with staff from the municipality and the hospital, partly from different departments? How did the supervisor experience the project? In what way have the organisations gained something out of having their employees participate in the intervention project?

\section{Background}

Those over 40 years of age have a higher sense of clarity in their profession and professional identity [17]. Personal contact in a tradition can help the older generation's knowledge wander over to the younger. Older employees have probably developed different approaches and tricks that facilitates their work during their long (working) life [5] [18]. To be made visible by being recognized for your experience and knowledge is also an important factor for health and to be able to work to a higher [19]. The best assessments and priorities are often based not only on factual knowledge but also on knowledge from previous experiences. Therefore, when older workers disappear from working life to retirement, the organisations loose important experience knowledge. Meanwhile, the younger generation are most likely carriers of new knowledge; it is of great importance that the elderly can take part of this new knowledge in order to be able to keep 
up with developments [20]. Learning through experience first and foremost is to learn something about the social relations [21]. This knowledge is personal and is difficult to convey to others. The same experience also gives different people different experience. To possess knowledge of experience may entail some power over those who do not possess the same experience. However, some older employees may feel that their position is threatened if, for example, new technology makes the knowledge of experience outdated and inferior [8] [20] [22].

Health and social care professions are one of the most common sectors among working women. Working in health care is often both physically and mentally exhausting. The work often consists of physically testing moments where the muscles and joints are subjected to heavy strain, which has been shown in sickness absence statistics. Health and care personnel without college education account for a disproportionate amount of sick leave [23]. People in the older age groups that disappear out of work are at a great risk of never getting back into working life. A study of long-term sick leave reveals that it was mainly in physically demanding occupations that problems arise for the elderly [24]. For the physically demanding professions in areas such as health care, there are not a lot of alternative tasks for the elderly who no longer cope with the physically heavy elements. Half of the reported occupational injury diseases in health care are musculoskeletal disorders [25]. Overall musculoskeletal disorders and mental illness counts for two-thirds of the long term sick leave and are the most common reasons for sick leave. Jobs in health care are usually called a human service profession, where employees perform their daily work in relation to a client, patient, resident in need of help [26]. Thus the work is often mentally stressing for employees to take care of other people, patients and relatives, worry, anxiety, disappointment and fears and creating support and participation relationships while they need to process their own feelings and reactions [27]. This can be very strenuous and uncertain in some situations. The perception of uncertainty and lack of control is associated with high levels of stress in working life research [28]. Care work is thus not only physically but also mentally stressful, through the ethical stress that staff is exposed to in their daily work. It can therefore be considered as important to health and social care staff that they are able to provide respite from the everyday work in order to be able to work to a higher age. Health professions can be regarded as practical professions in which knowledge and skills are mainly shown through action. Theoretical knowledge is a prerequisite to be able to take action, but not enough to give insight and act if the knowledge is not inserted in a specific context [29]. Care work is supported by the knowledge of practice, i.e. knowledge of how individual patients want things done. Knowledge of practice is bound to the individual and cannot be acquired through education. This knowledge of practice may not even be regarded as knowledge or even valued in comparison with formal education [30]. The knowledge acquired through literal tuition and books is describes as knowledge of assertion [31]. The knowledge based on insights on how, for example, people in health care must be addressed and treated based on life experiences, maturity 
and familiarity with similar situations is described as the knowledge of familiarity [31]. Health care workers conduct is controlled by the assessments made in a specific situation based on the collected experience and competence. It is when taking action in different situations that the occupational theory is tested and thus become available for reflection [29]. Theory and practice permeate each other and intertwine, and is central to the acquisition of knowledge based on familiarity in different situations [27]. Individuals' capacity for learning and reflection takes place largely by past experiences that create a net of association which in cognitive research is often called schemata [32] [33] [34]. Schemata can be likened to a program or instructions for action, reactions and expectations in different situations. Schemata seem to develop and improve over the years and older people appear to have more developed schemata than younger people. Occupational skills can be said to be built by schemata. There have also been tests with younger and older people that, for example, concluded that younger typists showed faster reaction times and scored more strikes per minute with the keys, but that older typists, in spite of this, were just as quick to finish writing a text because the elderly were more strategic in reading the text [33].

The knowledge obtained through experience in practice has different names by different scholars [27]. Some describe it as knowledge of experience, knowledge of practice; others call it knowledge of familiarity or tacit knowledge. Knowledge of familiarity is described not as the experience itself but the ability to process different events and experiences which can then be put into action. This requires a combination of theory, practice and reflection on what has been done. Familiarity can be said to be "silent" because it is work and knowledge that cannot directly be seen or measured [27]. Knowledge of familiarity or tacit knowledge requires a lot of thought that has been shaped by years of reflection on the daily work and woven into the structure of everyday life to then be used in exactly the right moment. Knowledge of familiarity is an aid to find the solution the specific situation requires. Time for reflection may be said to be necessary to create this type of knowledge. This report will not go into more detail on the different researchers' definitions of this knowledge, but use different names.

\section{Method}

\subsection{Method in the Intervention}

The method intended to be used for the transfer of knowledge in the intervention project was the case method. The idea behind the methodology is to learn through realistic situations. Case methodology was first used in the early 1900s on Legal and Finance programs in the United States. For instance, Harvard Business School used the case method to get into "reality" in their management training programs in the 1920s [35]. Today, more than 80 percent of classes at Harvard Business School are built on the case methodology. Case method is also used in developing areas such as health care [36]. The idea behind the case methodology is problem solving and familiarization exercise [37]. The strategy is to process cases and situations; formulate their own proposals and reach a solu- 
tion through group discussions. Sources of knowledge consists of, for example, designated materials, own search of facts and lectures. The supervisor or teachers role is to chair and lead the discussion, be responsive and get everyone to join the discussion and encourage the participants to talk to each other instead of to the leader.

Through meetings on specific situations in everyday life and with the help of case studies from everyday work can reflect on and develop their work in a group. Those who work with patients come together with their diverse skills to develop health care together. Case method based on a perceived everyday situation makes it possible to develop and document learning for both the individual and the group. By working with concrete situation, intriguing questions that are interesting to reflect often arise. Everyday situations can for example be about encounters with patients or meetings between employees. Questions like: What was it that made you feel that the situation turned out successful? What really happened? How did you do it? Should we try to rewind the tape? This also creates stories that illustrate an event with shades and moods, stories that can be documented and become case descriptions. The group highlights their everyday working life in a systematic way. Everyone listens and learns from each other. Thus their perspective widens and they are trained to reflect over actions.

The "case" can be divided into desktop case-based on someone's collective experience constructed a fictitious event, library case-a real event which was documented in some way in books, reports, articles, etc., as well as field case-a description of a real event by persons who participated or otherwise concerned [38]. The participants in this intervention wrote a diary/logbook between the occasions to find appropriate cases to discuss in the intervention project, but also to get ideas about which lecturers could be invited. There were guidelines and rules for how the cases were discussed and the following points were used as support.

1) Facts-what we know.

2) Problems requiring action (staff-residents-relatives).

3) Known and probable explanations as to how the problem occurred.

4) Measures (conducted and potential for staff, residents, relatives).

5) Expected effects/consequences.

Through processing and writing down the different parts of the discussed case story the knowledge of practice was not contained within an individual but becomes documented. The documentation was important and an educational part of the project.

The investigation was conducted according to the principles expressed in the Declaration of Helsinki.

\subsection{Selection}

An invitation was sent to several municipalities in Sweden to participate in the intervention project. The intervention project was described in the invitation as an arena for the transfer of knowledge of familiarity, an opportunity for relief from other work situations, a possibility for employees to be acknowledged 
trough their skills, as well as an opportunity to increase the transfer of knowledge of experience between county and municipality. The municipalities and hospitals that reported their interest first got the opportunity to start an intervention project for its care- and nursing assistants.

At an introductory meeting with the heads of the municipality and the hospital the ideas behind the intervention project were presented. The managers felt that this was a project they wanted to join and decided to proceed to their first line managers with an invitation to their employees, in turn, would be offered to be part of the project. Participants in the intervention project were selected to participate by the first line managers who received the invitation and offered to people who were over 55 years old or was under age 30 to participate in the project on the basis of "first come, first served" principle. Those who first reported interest were six senior and five junior care- and nursing assistants from the hospital and the municipality. There was only one man who participated in the project. One of the younger participants from the hospital only attended the initial meeting and was then absent despite the supervisor's attempts to get in touch with her. At various occasions the course leader/supervisor and a research assistant who followed and documented the project also attended in the intervention project.

Within the intervention nine focus group sessions were conducted. At the introductory meeting there was a presentation of the concept of the intervention projects purpose, method and goals of the participants. During the following meetings of the intervention project, different cases or problems brought up by participants were discussed in the groups. The number of participants at the sessions varied, but generally the number participants was high even though some activities did not arrange replacements for when the participants were absent from their jobs to take part in the intervention project (Table 1).

\subsection{Analysis Method in the Process Evaluation}

The intervention project was evaluated using three different methods:

1) through interviews with the participants and the supervisor;

2) through participant observation;

3) through an evaluation questionnaire to participants after the project was completed.

Table 1. The number of participants in the various sessions. The number is shown as in municipality health care institutions and home care + in medical care in hospitals.

\begin{tabular}{|c|c|c|c|c|c|c|c|c|c|}
\hline \multirow{2}{*}{ Participant in the sessions } & \multicolumn{9}{|c|}{ Session } \\
\hline & 1 & 2 & 3 & 4 & 5 & 6 & 7 & 8 & 9 \\
\hline $\begin{array}{l}\text { Older employees working: in municipality health care } \\
\text { institutions and home care }+ \text { in medical care in hospitals }\end{array}$ & $4+2$ & $4+2$ & $3+2$ & $4+2$ & $3+2$ & $3+2$ & $4+2$ & $3+2$ & $3+2$ \\
\hline $\begin{array}{l}\text { Younger employees working: in municipality health care } \\
\text { institutions and home care }+ \text { in medical care in hospitals }\end{array}$ & $2+3$ & $2+1$ & $2+2$ & $2+1$ & $1+1$ & $2+1$ & $2+0$ & $1+2$ & $1+2$ \\
\hline Total & 11 & 9 & 9 & 9 & 7 & 8 & 8 & 8 & 8 \\
\hline
\end{tabular}


Participating observation was a method selected to follow the progress of the intervention project, to get a better understanding of what happens in the group during the different sessions [39]. A group interview was arranged at the first meeting date to capture the participants' expectations for the intervention project. At the project's final meeting a questionnaire with open questions where participants could write down how they experienced the project was handed out. A final group interview with the participants also took place at the last meeting date. The supervisor was interviewed after the completion of the project to capture her experiences of the intervention project. The introductory and the concluding interviews with the participants were recorded while the interview with the supervisor was documented by notes. An informed written consent was obtained from the participants and the data were analysed anonymously. The information collected through observations, during the interviews and the survey is presented below in the Results paragraph.

The chronological order of methods used in the evaluation of the intervention project was:

1) Initial interview;

2) Observations of the participants during the seven intervention meetings;

3) Finishing interview with the participants;

4) Finishing interview with the supervisor in the intervention;

5) Evaluation questionnaire to the participants.

\section{Results}

\subsection{Description of the Intervention}

In Sweden the hospital health care are organised by the county and the home and residential health care of elderly is organised by the municipality, in most cases. The purpose of the intervention project was to create an arena for the transfer of knowledge of familiarity in health care work between younger and older employees in municipal and county care of elderly people. The intervention project was designed to give the participants an opportunity to concretize, highlight and disseminate their knowledge of familiarity to others. The participants were, through the intervention project, expected to develop the ability in everyday life to stop, reflect and put words to their actions. Furthermore the participants should understand that the skills they possess are worth something. The organisation as a whole expected to become less vulnerable and prepared for the imminent generational change in the health care sector by transfer of knowledge. The individual was even offered a break from the often stressful daily work situation that may be a threat to occupational health. This was expected to be a means to retain the workforce longer and, as a side effect of providing personal development, health economics and counteract burnout and ethical stress. The extension was expected to lead to the residents/patients receiving better care and nursing.

The intervention project describes knowledge of familiarity. Those who have worked for many years in the profession often have amassed considerable 
knowledge about how to deal judiciously and sensitively in different situations. Knowledge of familiarity is about how we, in our daily work, undertake complex tasks without being able to account for how we really do it. It is a practical, clinical knowledge developed gradually to more advanced capabilities as experience increases. It is such that allows employees to manage what is unique in each situation without having to follow explicit rules-in short: wise actions. It can for instance be a matter of reading the need of a patient who cannot express it themselves. Especially in critical situations it may prove important to have this knowledge to fall back on. There may then be a matter of recognizing patterns within the space of a few seconds. For that, they needed to know what to look for and what the possibilities are.

The project also highlights that it is of great importance to not only transfer older employees experience knowledge to the younger employees, but also transfer the younger employees' knowledge to the elderly. Those who were young in the profession also have valuable knowledge of familiarity. They were often grown up with computers and find it natural to search online in order to gather information to solve a problem that arises. They know where and how to find a problem and were advanced users of mobile phones, email and web-based communication. They were not afraid to embrace new technology when introduced in health care. This was applying to both technology information/communication and care.

In the intervention was it also important to discuss thoughts about employee health. By bringing in different tasks for those who have heavy care duties, it eases their everyday life. The intention was to strengthen the occupational health and the employee could remain in work until retirement age. This allows the work place to become healthier and the work to become more stimulating.

\subsection{The Participants' Experiences of the Intervention Project}

Participants in the intervention project had different expectations before the start-up of the project. Some were uncertain of what the project would entail, while others saw the knowledge of familiarity as the clear objective of the project. This is what some older and younger participants in the first group interview said: "I think $P$ ve learned a lot over the years and therefore have a lot to give and share with the younger people". (Older nursing assistant, municipality). Another older employees said: "I have worked for 40 years and have a lot to share to others of all ages. I also enjoy that the project is in collaboration with the municipality". (Older nursing assistant, hospital). A younger employees described: "My expectations are to get the opportunity to experience the knowledge of the older colleagues here in peace and quiet. In the daily care and the work it is difficult to find time to get it. Everyone is very busy. Patients cannot wait'. (Younger nursing assistant, hospital).

Were the participants' expectations fulfilled during the project? At the last meeting the participants described what they thought of the completed project. Someone seemed to feel that it had not been arranged simply to extract knowl- 
edge. A younger participant stated that she had expected to learn practical tips and advice from the elderly. She described it like this: "I expected more hands on advice and tips such as how to handle different situations in health care, practical knowledge, technical skills and so on. As a younger person, I need the knowledge and the elderly have the experience, but it seems that the elderly have difficulty to convey their knowledge. I...I The elderly keep their knowledge to themselves and convey it only verbally when they are questioned directly". (Younger nursing assistant). This younger participant did not seem to receive what she had expected out of the project. She thought that the older people withheld their knowledge and were not really willing or able to convey it. However, all participants indicated that they were very satisfied and described the project as an inspiring experience that added much to the daily work. To participate seems to be very vulnerable for the older employ because they felt their experience knowledge was important to the organisation. Some said: "I will miss it. /.../ Everyone have been seen for what they are here, you don't get that every day". (Older nursing assistant, hospital). Another said: "I think it has been fancy, being my age and having the opportunity to participate in the intervention project. You'd think there soon will be nothing left for us older employees". (Older nursing assistant, municipality). Another said: "It has brought a lot of things that you might not have thought of before. It has started a lot of things going on in my head, so I have almost not been able to be quiet /.../ Sometimes 1 ve been thinking to myself'stop talking I need to say something' /.../ Memories that I have carried with me were confirmed here, like we did that and this is how we do it now. There are more things that I have thought about. I have been in healthcare for many years and it has changed very much /.../ like the way of looking at our patients today is quite different from what it was in the $60 \mathrm{~s}$ 70 s... This has tied up then and now.... The approach towards humans and humanity was zero back then. Today it's different'. (Older nursing assistant, hospital)

The possibility to get specified time to talk and learn from each other was very important to both older and younger employees. Some also said: "In the intervention project we have been able to talk about things that you really would like to ask on the job, but there has been no time to do so. Then we have been able to bring it up here and talk about it". (Younger nursing assistant, hospital). Another said: "I will miss going here. I prioritised going here even though they do not put in a replacement nursing assistant and I need to keep my phone switched on". (Older nursing assistant, municipality).

Several participants described that in the future they would most likely miss the intervention project. To get the opportunity of being able to calmly sit down and discuss the problems of everyday life and feel empowered and seen by others. In what terms were these group meetings different from the usual meetings in the daily work? There appeared to be primarily the ability to meet in peace and quiet outside of work where the intention was precisely to tell and share each other's stories and reflect over these together. This was perceived as very 
satisfactory for the participants in the intervention project. Here is how some expressed participants this in the project: "I feel I have got a chance to talk about things that I have been carrying and thinking about. I sat here and got other people's reflections on this, which is important. That someone have questioned, why did you do that, you could do it this way instead. It is quite important to know that this is a safe place. Where it's safe to tell' (Older nursing assistant municipality). Another said: "Many things are still in process. /.../ There are things going on in my head still. It has been safe here and a lot to discuss, but there has not been any pressure that you should talk about something in particular. In some of the meetings we talked about what we feel and we want to share with each other. I.../ Some lecturers have also been very good and talked a lot about grief and so. I feel that sometimes this pops up and I reflect on it. So I think that we will benefit from this in the long run. Even more than you might see today." (Older nursing assistant hospital)

Learning is done when reflecting on an action or something that has happened, only after there this you may learn something; taking advantage of the experience in future situations. You may not have time to reflect on what happens when you work and therefore you learn nothing from it. One basic idea of the intervention project was to give the employees the opportunity to reflect by themselves and with others and exchange knowledge in peace and quiet.

Some of the participants stated that they often lay thinking about work and what had happened during the work at night. Someone described: "The thoughts come at night when you cannot sleep". (Younger nursing assistant, municipality). The possibility to reflect and discuss the cases make this be better. Some said: "I have earlier missed the time and possibility to sit down and reflect. I.../ I have worked many years in health care and not always felt very good. What I have noticed is that when I get to talk and put things out on the table here, it's gone in a completely different way. I do not need as much answers as I need to talk about it. Saying things out loud makes it easier to get through it'. (Older nursing assistant, hospital). The intervention project seems not only to be a place of reflection and knowledge, but also a protected zone where participants could talk about the kind of problems that they would ponder over, for example, at night. One purpose of the project was that the intervention project would act as a valve and relief from the regular work, which thus appears to be met.

\subsection{Transfer of Knowledge}

One of the aims of the intervention project was the transfer of knowledge between different fields, that is, between generations, between different departments and between the municipality and county. The definition of knowledge, however, is very broad and some of the participants wondered about the definition of knowledge and said this: "Knowledge is so much. It has a lot to do with insight as well, not just technical things that one often associates to the word knowledge when at the hospital. It does not need to be instrumentally, it is a much broader concept'. (Older nursing assistant, hospital). Another said: 
"Knowledge may be a lot of different things, even practical. One takes it for granted when one is at work, that you can do it". (Older nursing assistant, municipality).

Those who participated in the intervention project all seemed to have a scientific knowledge basis due to their education and work in health and medical care. Seeing their daily actions at work as a product of their collected knowledge of experience did not seem to be entirely obvious at first. At the initial interview, someone described that they would transfer their knowledge through show and tell, while someone else was hoping for heated discussions. Did the participants experience that there had been any transfer of knowledge at the end of the project? Someone said: "There has clearly been transfer of knowledge. I have assimilated a lot of knowledge and I am convinced that I have handed over a lot of knowledge". (Older nursing assistant, municipality)

If we take a look at which exchange occurred in the various fields a picture emerges, where it seems that a variety of fields have been cross-fertilised. For example, it could be discerned that there has been an exchange of experiences between the different generations, which was a basic objective of the project. Several people described how it had been fruitful to discuss and reflect on the differences in working today compared to before. An older participant described that when she as a new employee had not dared to ask the elderly, but that this did not seem to be a problem for young people who were hired today. She said this: "In the past, when I began to work, I did not dare ask. If anyone questioned why you should do something in a certain way the nursing assistants just answered - don't ask just do it. After that you dared not ask. So you just did what they said and taught yourself'. (Older nursing assistant, municipality)

The younger participants described that it was interesting to listen to some of the older stories of how health work used to be and some of the older nursing assistants missed the time when there was more time to sit on the bed side and talk to the patients. Some said: "It has been interesting to talk about the differences between how they worked before and how we work now. I have been brought up in this 'not having time to sit on the bed side' and I have this thing about documentation with me, I can absolutely both see advantages and disadvantages with how it was before, clearly. This time aspect has been very interesting to talk about". (Younger nursing assistant, municipality)

Some differences between generations regarding work were also revealed, which appeared to be a small source of irritation between the generations in their daily work. For example, documentation was discussed intensely and reoccurred several times during the project. The younger ones stressed the importance of documentation; while the older ones felt there was no need to document as much as some younger people did today. Someone described the discussions on documentation as follows: "It felt great when someone brought up that they did not think documentation was crucial, and that the time should be spent on the patients. It felt very good that someone else said it; I want to spend my time working with the elderly and not sit by the computer. The younger ones think 
it's easier to document than we older people do, I think." (Older nursing assistant, municipality). However, a younger participant described the difference in the perception of documentation could also be due to the tasks and said this: "We younger people might have more interest in computers and documentation, plus depending on what department you work in the documentation varies regarding importance. In the emergency room there is not much time to sit down with patients, and when they should proceed in receiving care; if their visit is not documented, they have nothing. Therefore I almost see documentation as the most important task for us". (Younger nursing assistant, hospital)

Both older and younger participants outlined that it had been successful to take note of each other's views and reflect on different approaches. A younger participant described that after a lively discussion in the intervention project and by reflecting on the older participants' experiences, she had changed some of her practices. She described it like this: "I have campaigned so much for documentation and still do, and think it is something important. But at the same time I thought that I might have put a little too much energy on it. Maybe I should talk a little more with my patients and add an extra minute there. I ve probably changed my mind a little regarding this matter. So P ve learned something even if I felt 'ugh' when I heard it to my face. After I came home, I thought further about it, and thought that we all have to try". (Younger nursing assistant, municipality). It appears that the intervention project indeed has transferred knowledge and knowhow between generations and to the participants. By sharing the experiences of others and reflecting over this the participants developed their working methods.

Participants described that it had also been an exchange of knowledge between different departments, which resulted in a more open approach towards different ways of working. Some participants described it like this: "I think we have learned a lot from how other departments work. /.../ How others work has been very educational for me". (Older nursing assistant, hospital). Another said: "You've gotten deeper insight into what other departments are doing. We definitely do not work in the same way on the different wards of municipality organised health care and county organised health care". (Younger nursing assistant, hospital).

During the initial interview, several of the participants described that they were interested in participating in the intervention project because it is important to strengthen exchanges between the county and municipality, among other things. Some even described it would be interesting to see how the cooperation between the county health care participants and the municipality health care participants would work out. This was because quite often there were misunderstandings and sad faces in daily work between the two organisations. Some of the participants described their expectations for cooperation between municipalities and counties before the project began like this: "It's different to work within the municipality and within the county. This intervention can increase understanding between us'. (Younger nursing assistant, hospital) Another 
younger employee said: "Many of the patients who come to hospitals (county health care) today are elderly so it's good if we could get a better collaboration on how we will work' (Younger nursing assistant, municipality). An older employee reflects: "I have often thought that it would be good to try working in the municipality in order to know how they work there. Perhaps one can get to know now" (Older nursing assistant, hospital).

A clearly stated expectation was that the project would create greater understanding between the municipality and county. Because of this it was interesting to study if these expectations were fulfilled by the project. This is what some of the participants said when the project was completed: "Now P ve seen the faces of the people working in the municipality /... I ve missed this because I have not worked in the municipality but we have a lot to do with them, or rather we send many people to the municipality. Despite this we rarely see the workers and I have not really known what they want from me. Instead the assistance officer is there. I.../ This has actually taught me something and I feel more for them instead of how it was before, like - Why are they doing this! Now you know a little bit more why so it's been good to learn". (Senior nursing assistant, hospital) A younger employee said: "I have worked both in the municipality and the hospital, and think it would have been good if we had had more of these types of meetings between hospital and municipality so that they have time to ask one another -Why do you do this and why do you do that? I think you learn from each other and understand each other in a completely different way. I believe this could lead to better cooperation between the county and the municipality". (Younger nursing assistant, hospital). Another younger employee describe that the intervention was an important initiative to make a better collaboration between municipal organised and county organised health care, and that the patient could get a better treatment and care. One said: "Now, when you got to know the people in the hospital you dare to ask stupid questions about what they are doing and so on. Earlier, I did not dare to do so. By then it was like we stood on either side of a wall, and no one dared to question the other, which results in no communication. I absolutely believe that it is important that in this way demolish some walls between the municipality and county". (Younger nursing assistant, municipality)

The transfer of knowledge of how to work within the municipality and the county was described by several participants as the most important outcome of the intervention project. The obstacles and problems that occurred in the work situations between the municipality and county were described as more common than the issues which arose between the generations. This is how one participant describes it: "The wall between the municipality and county are higher than among younger and older. The wall is harder to exceed than that between colleagues with an age difference". (Younger nursing assistant, municipality)

It was clear that the participants felt that the cooperation that occurred between the municipality and county was the most rewarding outcome of the project, which some described as follows: "The cooperation between the municipal- 
ity and county has been the most rewarding; there is a better understanding now. I think that I have conveyed things to others about what we do in the municipality. Purely practical things you maybe did not know, which you then pass on to your colleagues. And I have found out things about working in the hospital that I have passed on". (Younger nursing assistant, municipality). Another describe: "Purely practical stuff has also come up during the discussions. $1 \mathrm{~m}$ working in the municipality asked the employees of the county - How do you do this and do you know how we do it in the municipality? -No, they said. And so I told them and we had an exchange. It has been great, I think, because it 's been about things that one might think about-Why don't they do it like this ... and they don't even know about it, and vice versa". (Younger nursing assistant, municipality).

Participants in the intervention project also described that in future they wanted more interaction between the municipality and county to deepen cooperation between the organisations. Several said that they would like to visit each other's work and go next to the employees there for a day to increase understanding and knowledge further. Someone said this: "I have become more interested in seeing the municipality's work. One would like to come and visit and see some more. So that it all will lead further". (Older nursing assistant, hospital). Another describe: "What $P$ ve missed in the project is to see and follow another example; those who work in the municipality or elsewhere in the house (hospital) are included in this. Some of us have talked about it here but it will not mean that a regular working day can be spent following someone else; it should be a part of work to do it. I miss that. Although we have been talking a lot here, I would like to see it with my own eyes. It has aroused the curiosity and so I would like to see more". (Senior nursing assistant, hospital). Several participants describe that it was important to develop and continue the work that the intervention project set in motion.

\subsection{The Management of the Project}

As described previously the intervention project was based on a concept that was previously tested in a pilot project at a hospital in southern Sweden. The supervisor for the intervention project recruited and came into the project after the methodology and project-sketch was finished. She stated that she felt the completed project as more positive than expected because she had felt unsure of the projects' purpose in the initial stage. What did the participants think of the management of the project? At the initial interview, the participants described that their expectations of the supervisor of the project was that she would steer and keep the discussion on track so that they would not lose focus. The supervisor was expected to pick up on the knowledge the participants possessed. How did the participants see supervisor's role in hindsight when the project was completed? It turned out that all the participants were very satisfied with the supervisor and the methods she used in managing the project. Many also indicated that they had seen it as an advantage that the supervisor had worked in the area 
and knew the field. Someone said this: "The supervisor has led us when we have freaked out about 'now we will be here and talk about this and that', this above all, and also providing support'. (Younger nursing assistant, municipality). Another said: "The supervisor has worked just excellent I think. She has been a huge knowledgeable in the area that we are working, which has been an advantage. /.../ She has not driven the discussion, but started it". (Older nursing assistant, municipality). The participants seemed to be very happy with the way the supervisor pushed the project and the modified case-method she had used to adapt the method to the purpose of the intervention project.

\subsection{The Supervisors' Experience from the Intervention}

The supervisor was the one who set the tone and guidelines for implementation of the project and thus had a significant role in the intervention project. The supervisor described that she worked in the fields in which the participants worked. Therefore, she saw the project as very important not only as an opportunity for transfer of knowledge, but also above all as an opportunity for participants to get away from the daily work, be unloaded and given the opportunity to reflect on their everyday situation. This indicated that it is very important to cope with the sometimes very demanding health care and social work. The supervisor described the mixed groups as a big advantage. The groups had been mixed well with younger and older, different kinds of nursing- and care assistants, and not least with the municipal and county employees. She felt that this type of project had major benefits for organisations, patients/residents and the employees themselves. This is because the project had provided the exchange of knowledge that is helpful in care planning. The staff who were closest to the residents had even had the opportunity to sit and reflect on various problems and thoughts in peace and quiet without being stopped in the middle of a thought, which increased requirements for better care for patients and therapeutic unloading of stressful events and problems for the staff. The supervisor described that the organisation, in turn, also won this since they got a more positive and relaxed staff back. This type of project could, according to the supervisor, to some extent relieve the managers because they often have difficulty finding time to discuss arising problems and situations of all the individual employees. The supervisor's view was that the knowledge that the participants gathered in the intervention project had been forwarded to other staff in their home organisations by the participants, for example, how the other departments, municipal/county made in different cases. Thus the knowledge had even spread to more people than the participants in the intervention project.

The supervisor also describes some problems in the intervention. The supervisor stated that she had not previously worked with the case method; in spite of this she had not received any clear instructions of the method or supervision during the project, although this was in the project description. The supervisor instead had searched for literature on the subject at the library and on the Internet to learn about the case method. The supervisor also contacted the supervisor 
for the intervention project in another municipality to discuss the method and the concept of the project. She felt that the case method was a useful basis method in the intervention project and has continued to use the method in other contexts. The supervisor was left to interpret how she would use the case method for the intervention project. She went through the method with the group and used the case-method matrix at one time so that all participants could write down what was discussed. The supervisor felt that the case-matrix was partly obstructing the discussions and decided to modify the method to instead steer the discussion so that the subjects on the matrix were addressed in the general discussion rather than to actively discuss one subject at a time for each case/ problem as often is customary in the case method.

\subsection{The Experience of the Case Method}

In general, all participants took part of the group discussions, although some spoke more than others. Some of the participants described the group discussions as follows: "We came here and sat down. Since then the discussions have been in full swing about various topics and no one has found it difficult to talk /.../ everyone had something to contribute". (Older nursing assistant, municipality)

At the initial meeting and at the first intervention project meeting a careful review of the case method was made. In the subsequent meeting the discussion started based on some of the participants suggested cases. These cases were then discussed based on the case-matrix that was handed out to the participants and the discussion was guided by the points marked on the matrix. During the remaining intervention project meetings the case-matrix had a subordinate role and instead the supervisor managed the discussions so that the cases and problems touched most points the case-matrix without focusing on the matrix. How did the participants experience the case method used in the intervention project? Someone described it this way: "It's been very simple; I do not think there has been a problem for either of us. We have sort of been led into a certain path and then it all has continued in its own way. When we have ever fallen out of the frames, the supervisor brought us back again." (Older nursing assistant, municipality). Another said: "Case method was completely new to me, but I thought the best thing about it was when it started up and one was able to see in complete clarity that some things one might not even be able to do anything about, but you see it in a different way." (Older nursing assistant, hospital)

The case method thus served as leverage in the discussion, but the method itself was subordinated. It has raised other important issues during the discussions that have not been put aside to merely follow the original case story/problem as is often done when working through the case method. The meetings in the intervention project varied in content, due to what the participants wanted and needed to discuss. This is how some participants summed up the last meeting sessions: “Work has been a lot about different relationships, patients, approaches and not concerning age differences, but also other things in the work ... And of 
course the time aspect, then and now". (Older nursing assistant municipality)

The project description of the intervention project stated that lecturers could be invited. At the first meeting sessions the participants were therefore asked to come up with suggestions on lecture content or specific lecturers. This resulted in lecturers being invited on two occasions. The topics that the participants suggested were stress and stress management, as well as sorrow and managing sorrow. The lectures were appreciated by the participants and described to bring another dimension to the discussions. Someone described it this way: "They contributed a lot actually, especially the priest and the deacon who talked about grief and mourning". (Older nursing assistant, municipality)

At the various meeting sessions very lively discussions took place. In order to create a suitable climate for discussion in a group, the group size and the physical environment also have a certain importance. Those were included in the intervention project in one of the municipalities; the group had been small enough for everyone to feel comfortable with talking about slightly sensitive topics. Participants also described that they felt that the room, with a large round table, had been an advantage in the discussions when they all were able to see each other.

The project description stated that the documentation of the case/problem under discussion would be an important and rewarding part of the job. However, the participants did so only at one of the meeting sessions. In hindsight the supervisor described that she was uncertain whether she should have kept more strictly to the method and for example used Case-matrix more in the discussions and been more careful to document and raise any point. However, she believed that this would have stifled some discussions which had now become fruitful. Case method had instead become a railing to lean back against when some discussions drifted away from the original topic. The group sometimes slipped from the subject and discussed and reflected on more mundane things in the society. However, considered the supervisor, this is actually almost as important as reflecting on work situations because the society and attitudes affects the health care employees in many different ways and is also needed to be reflected.

\section{Discussion}

In the ageing society more older employees need to stay in working life for longer and the society need to take care of the increased amount of elderly in a more effective and respectful way [1]-[9]. New methods and measures is needed to be developed and evaluated on how to take care of older employees experience knowledge to make the elderly care and the care employees work situation better and self-crediting to go on in an extended working life [10] [11] [12] [13]. This intervention projects' objective was to transfer knowledge, both between generations and between different activities, i.e. between county and municipality. The overall purpose of this article was to evaluate how the participants in an intervention project experienced the project and its methodology. The study includes a descriptive process evaluation of an intervention project of the transfer of knowledge between younger and older employees in the health- and medical 
care. It purposes how the participants and the supervisor experienced the project. To summary the participants stated that the intervention project was successful and the case-method was very useful to transfer knowledge between younger and older employees and between different activities.

\subsection{The Participants' Experience of the Intervention Project}

In an intervention project it is important to spread and transfer knowledge between employees [36]. As previously disclosed, several of the participants indicated that the transfer of knowledge between the different activities was the greatest benefit of this project. Participants in the intervention project indicated in the initial interview that they mainly expected the project to offer them an opportunity to obtain and share their knowledge in peace and quiet. Most people seemed happy and felt that the expectations they had of the project were realised. Someone stated that the aim of the intervention project had primarily been at exchanging knowledge about the soft values in the care work, and not as much about the technical and practical work steps. Possibly the intervention project was not the right forum for the transfer of technical knowledge in the care work, such as needle insertion. The transfer of this type of knowledge is likely requires that you learn this by watching an experienced colleague instead [29] [30] [31]. The ability to walk next to any of the other participants in their daily work was something that was called for by several of the participants. Hopefully the organisations value this desire and continue to build the link between the health care employees at the municipality and health care employees at the hospital that the intervention project created. Earlier studies indicated that this could be developing and sustainable to both the organisation and to the older employees' health and motivation to an extended working life [7] [8] [10] [11] [12] [13] [22].

However, one of the younger participants indicated that she was disappointed that the elderly did not really want to let go of their knowledge, but just passed it on if they got a direct question. Sometimes those with a particular knowhow take the knowledge for granted and do not understand that other one do not have the same experience. Although other studies suggest that experience knowledge means a certain power [19] [33] [40]. The elderly may also experience their position threatened when for example, new technology makes their knowledge quickly outdated. The older nursing assistants saw their approach as threatened and that the younger to a certain extent saw the elderly approach as outdated was traceable through the lively discussion that occurred between generations when for example the importance of documentation was discussed at several meetings.

The intervention project seemed to be the valve and relief for the participants as the project description intended it to be. The protected zone that has been highlighted as the importance of primarily older employees in physically demanding professions to have less risk of suffering long-term illness [23] [24] [27]. The presence at the various sessions of the intervention project was good. 
This despite the fact that somebody had not received a replacement but had to work over the time that they went away or had their phones switched on in order to be reachable during the meeting time. Getting a chance to sit down and discuss the things that came up in everyday situations at work, that the participants had been carrying and not had the opportunity to discuss and reflect on was stated to be so rewarding that this was a major priority, and followed one of the aim of the intervention [29]. Care work is not only physically but also mentally exhausting since staff must perform their practical tasks while they have to constantly attend to the patients, relatives and their own feelings [26]. This can lead to excessive stress on the employees if they do not get the opportunity for relief and to experience control of the situation [28]. The project participants were able to get away from the daily work in peace and quiet to sit down which can be said to be both physical and psychological relief while several participants seemed to experience a therapeutic benefit of the group meetings. Previous research has shown that older employees are demanding relief to be able to work to a higher age [7]. The older employees who experience work more stimulating desire in even greater extent to work until a higher age [8]. This was something that the intervention project also intended to contribute to and seems to be satisfied.

\subsection{The Management of the Project}

Participants in the intervention project stated that they were very satisfied with the supervisor's managing of the project and meeting sessions. They indicated that the supervisor was very knowledgeable in their fields of work, which they saw as an advantage in the discussions. The supervisor in turn also seemed very pleased with the project and its results. This despite the fact that she had been worried initially when the method and the concept was new to her and she seemed to have experienced a lacking support of how the method could be used. The supervisor had through her previous experiences and acquired knowledge by herself to interpret and modify the method to suit the purpose of the project. To "read" a group of individuals based on previous experiences, maturity and insight and use the right treatment is based on the knowledge of familiarity [31] [41]. It was thus clear that the supervisor herself was bearer of the knowledge familiarity that she used to modify the case method to fit the group instead of just using the fetched knowledge of how to use the case method. The supervisor's knowledge of familiarity thus became very important for the discussions to become fruitful in the group and not disturbed or held back by literally follow a method. The supervisor did not think it was a problem that the participants of the intervention project had not kept records on the case-matrices and that knowledge of practice had not been documented, which is described as part of the method in the project description. This is because she was convinced that the knowledge of practice was carried and spread by the participants and their colleagues.

\subsection{The Intervention Method}

The transfer of knowledge can be facilitated by creating personal contact be- 
tween generations within a tradition [17]. Therefore the intervention project seemed to be an excellent forum for knowledge transfer, as described in earlier research [35] [36] [37] [38]. Participants generally felt that the case method was a good starting point to debates in the group, even if not strictly adhered to the matrix with clearly defined points that was available. Participants seemed to prefer that the discussions were not limited to a clear framework, but could slip back and forth between different fields. It was possible to discern that they were confident that the supervisor brought them back when they drifted too far from the subject. That the various participants have had the opportunity to give their views on the matter and vent and share experiences has been the superior method in the intervention project. The participants and their cases/problems have been in focus, not the piloting of a specific knowledge transfer methodology based on case-method.

The intervention project has thus not exactly followed the case-matrix points and made notes on the discussed case [38] [41]. Participants have not brought a stack of recorded cases with different obstacles and proposed solutions. Participants instead received something for their personal development and to their home organisation, namely the strengthening of confidence and knowledge, the power of reflection in generating and disseminating new knowledge and understanding of other activities and their working method. It is through reflection on actions in different work situations that the occupational knowledge is tested and developed [29]. It therefore seems important to give employees the opportunity to quietly reflect on different actions through projects like this.

Several of those included in the intervention project stated that it was not easy to define knowledge because it was such a great concept. They seemed to be unanimous that the project did indeed generate and transfer knowledge. Social relationships are an important part of learning through experience [21] [37]. Participants in the intervention project seemed to agree with this because they stated that they gained new knowledge through reflecting and discussing different cases/problems/situations. Some participants also described that they could easier to see past mistakes and shortcomings in their work and had processed past events just by talking about them with others. It is important to re-reflect on the daily work [29]. If health care professionals do not get the opportunity to deliberately and systematically record what she/he has learned they will not develop the experience [36]. A prerequisite for competence is that health professionals are able to reflect on their actions and the situations that arise in everyday life. Employees cannot reflect during work, this may instead lead to same mistakes being repeated over and over again.

At the initial group interview a younger nursing assistant from the municipality expressed that she thought it would be exciting to be part of the intervention project, but she was also a little concerned about how she would be able to convey knowledge to others in their own workplace. She described her concern that the intervention project would be a group that learned from each other but who would not be able to convey the knowledge to the home organisation. At the fi- 
nal interview the participants did not seem to feel that her concerns had come true. Organisations are composed of individual employees who together form the business. By getting the opportunity to vent different cases/problems/opportunities the participants described that they got new knowledge about the course of action and thought. They had also gained knowledge from other work activities which they passed on to their colleagues, knowledge that became permanent in the daily work. Several participants also testified that the project had started some new thoughts on the problems and approaches, a process which only seemed to be at an early stage. The background section of this report describes that the cognition researchers approach to learning is largely consisting of new knowledge being interwoven with past experiences, i.e. an individual extended field of knowledge [32] [33] [34]. Professional knowledge is often based on experienced knowledge together with theoretical knowledge [27] [30] [31]. Based on what the participants of the intervention project describe, they have expanded their schemata, experience and practice of knowledge and thus, they have probably also developed their professional skills through the project. The theoretical knowledge is important but needs to be supplemented with experience of actions in specific situations to provide experience, knowledge of practice and familiarity.

A limitation in the study was the small study group and could therefore not be stated as general. The Method need to be tested additionally with other participations and also in other countries. However, the case-method has successfully been used in other interventions and educational projects since the early 1900s [35] [36] [37] [38]. That directs the robustness of this intervention method. Another limitation was that especially the younger participants had problem to participate in the meetings when they have too much to do in their daily work and activities. That is a paradox because earlier research stated that older employees often have developed method to handle their tasks and daily work in a smoother and more effective way [31]-[34], and one of the projects objective was to transfer the older employees knowledge on this to the younger employees.

\section{Conclusion}

"I think it is a lot about that we come from different areas. It is not just age and that some are older employees and other are younger employees. But it is also about how some of us work with health care of elderly in the municipality and others in the county. Thus, we can explain how we do things from our direction to transfer it to the next group, which in turn raises questions - Why do you do that? And so on. You are deep in discussion right away". (An older nursing assistant)

The quote above can be said to be a summary of the complexity in the cases, and what has been the core at the meetings of the intervention project. The aim was that the project could serve as an opportunity to get away from the daily work to a protected zone where participants exchange experiences and reflect on the various events and problems in daily work. Participants appear to have ex- 
perienced that their experience was made to be visible and their professional competence has been strengthened. They indicated that there had been an exchange of knowledge and not only between the generations but also between different kinds of work. The organisations also seem to have gained from the project by allowing the participants to unload, become more positive, develop more knowledge of experience, increase their propensity for reflection and get a better consensus between the municipality and county. The developed methods and measures in this intervention project seem to be a way to take care of older employees experience knowledge to make the elderly care and the care employees work situation better and self-crediting to go on in an extended working life in the ageing society. Due to the evaluation, this intervention project promotes both a better care and treatment of elderly people in municipality organised and county organised health care, and a better work situation and self-crediting for the employees in all ages. The intervention project seems to have fulfilled the stated purpose and also the expectations of the participants and the work situation seems to be more sustainable for the older employees.

\section{Conflicts of Interests}

All authors agree with the content of the manuscript and there are no conflicts of interests.

\section{References}

[1] Beard, J.R., Biggs, S., Bloom, D.E.F., et al. (2011) Global Population Ageing: Peril or Promise. World Economic Forum, Geneva.

[2] United Nations Fund for Population Activities and HelpAge International (2012) Ageing in the Twenty-First Century: A Celebration and a Challenge. United Nations Population Fund for Population Activities and HelpAge International, New York and London.

[3] Rechel, B., Grundy, E., Robine, J.M., et al. (2013) Ageing in the European Union. Lancet, 181, 1312-1322. https://doi.org/10.1016/S0140-6736(12)62087-X

[4] European Commission (2010) Demography Report 2010. Directorate-General for Employment, Social Affairs and Inclusion. Eurostat: The Statistical Office of the European Union, Luxembourg.

[5] Nilsson, K. (2013) To Work or Not to Work in an Extended Working Life? Factors in Working and Retirement Decision. Faculty of Medicine, Lund University, Lund.

[6] Nilsson, K. (2016) Conceptualisation of Ageing in Relation to Factors of Importance for Extending Working Life-A Review. Scandinavian Journal of Public Health, 44, 490-505. https://doi.org/10.1177/1403494816636265

[7] Nilsson, K., Rignell, H.A. and Rylander, L. (2011) Factors Influencing the Decision to Extend Working Life or to Retire. Scandinavian Journal of Work Environment \& Health, 37, 473-480. https://doi.org/10.5271/sjweh.3181

[8] Nilsson, K. (2012) Why Work beyond 65? Discourse on the Decision to Continue Working or Retire Early. Nordic Journal of Working Life Studies, 2, 7-28. https://doi.org/10.19154/njwls.v2i3.2361

[9] Ilmarinen, J. (2003) Promotion of Work Ability during Aging. In: Kumashiro, M., Ed., Aging and Work, Taylor \& Francis, London, 23-39. 
https://doi.org/10.4324/9780203218556_chapter_3

[10] Oude, H.K., Blatter, B.M., Geuskens, G.A., Kopples, L.L.J. and Bongers, P.M. (2011) Factors Associated with the Ability and Willingness to Continue Working until the Age of 65 in Construction Workers. International Archives of Occupational \& Environmental Health, 85, 783-790. https://doi.org/10.1007/s00420-011-0719-3

[11] Kindberg, U. and Wallin, G. (2000) Den Lönsamma Balansen: Om Alternativ till Arbetets Förtärande Stress. [The Profitable Balance: Alternatives to the Consuming Work Stress.] Swedish National Institute of Working Life, Stockholm.

[12] Nordenmark, M. and Stattin, M. (2009) Psychosocial Wellbeing and Reasons for Retirement in Sweden. Ageing \& Society, 29, 413-430. https://doi.org/10.1017/S0144686X08008179

[13] Vaus, D.W.Y., Kending, H. and Quine, S. (2007) Does Gradual Retirement Have Better Outcomes than Abroupt Retirement? Results from an Australian Panel Study. Aging \& Society, 27, 667-682. https://doi.org/10.1017/S0144686X07006228

[14] Bonomi, S., Za, S., Marko, M. and Rossignoli, C. (2015) Knowledge Sharing and Value Co-Creation: Designing a Service System for Fostering Inter-Generational Cooperation. Lecture Notes in Business Information Processing, 201, 25-35. https://doi.org/10.1007/978-3-319-14980-6_3

[15] Hylmo, A. and Speckman, L.E. (2010) Knowledge Transfer and Mentoring the Next Generation of Aerospace Engineers: A Case Study for Strategic Intervention. Capital Airlines Incorporation, Anaheim.

[16] Nilsson, K. (2016) Interventions to Reduce Injuries among Older Workers in Agriculture: A Review of Evaluated Intervention Projects. WORK: A Journal of Prevention, Assessment, and Rehabilitation, 55, 471-480. https://doi.org/10.3233/WOR-162407

[17] Rolf, B. (1991) Profession, Tradition och Tyst Kunskap. [Profession, Tradition and Silent Knowledge.] Nya Doxa AB, Övre Dalkarlshyttan.

[18] Hallsten, L. (1996) Arbete och Psykologiska Aldersförändringar. [Work and Psychological Changes in Age.] In: Aronsson, G. and Kilbom, A., Eds., Arbete efter 45. Historiska, Psykologiska och Fysiologiska Perspektiv pa Äldre i Arbetslivet, Swedish National Institute of Working life, Stockholm, 133-172.

[19] Bengtsson, E. and Nilsson, K. (2004) Äldre Medarbetare-En Kvalitativ Studie om Medarbetares Villkor i Arbetslivet Inom Hälso-Och Sjukvarden. [Older Workers-A Qualitative Study about Employees Conditions in the Health Care Working Life.] Swedish National Institute of Working life, Malmö, 1-127.

[20] Nilsson, K. (2011) Attitudes of Managers and Older Employees to Each Other and the Effects on the Decision to Extend Working Life. In: Ennals, R. and Salomon, R.H., Eds., Older Workers in a Sustainable Society, Peter Lang Verlag, Frankfurt am Main, 147-156.

[21] Billgren, B. (1990) Tyst Kunskap-Nagot att Lyssna till i Framtidens Vard! [Silent Knowledge-Something to Listen to in the Future Health Care!] SHSTF Forskning och Utveckling, Stockholm.

[22] Nilsson, K. (2006) Äldre Medarbetares Attityder till ett Langt Arbetsliv: Skillnader Mellan Olika Yrkesgrupper inom Hälso-Och Sjukvarden. [Older Workers Attitude to an Extended Working Life: Differences between Occupations in Health and Medical Care.] Arbetslivi Omvandling, 10, 1-69.

[23] Arbetsmiljöverket (2015) Kvinnors Arbetsmiljö 2011-2014. [Women's Work Environment 2011-2014.] Swedish Work Environment Authority, Stockholm.

[24] Rensing, M. and Sandmark, H. (2005) Kvinnors Sjukskrivningar: Intervjuer med 25 
Langtidssjukskrivna Kvinnor i Mellansverige. [Women's Sick Leaves: Interviews with 25 Women on Long Term Sick Leave in Middle Sweden.] Karolinska Institutet, Institute of Public Health, Department of Occupational Medicine, Stockholm.

[25] Bengtsson, B. and Sollenberg, M. (2005) Organisatoriska eller Sociala Faktorer i Varden. [Organisational or Social Factors in Health Care.] Swedish Work Environment Authority, Stockholm.

[26] Lipsky, M. (1980) Street Leval Bureaucracy-Dilemmas of the Individual in Public Servies. Russel Sage Foundation, New York.

[27] Davies, K. (1996) Önskningar och Realiteter. Om Flexibilitet, Tyst Kunskap och Omsorgsrationalitet i Barnomsorgen. [Wishes and Realities. About Flexibility, Silent Knowledge and Care Rationality in Child Care.] Carlssons, Stockholm.

[28] Aronsson, G. and Lind, T. (2004) Langtidsfriskas Arbetsvillkor: En Populationsstudie. [Working Conditions for Long Term Healthy People: A Population Study.] Arbete och Hälsa, 10, 1-25.

[29] Kennedy-Olsson, B. (1995) Praktiken i Focus: Sjuksköterskors och Studenters Samspel och Kompetensutveckling i Klinisk Praktik. [Practice in Focus: Nursing Assistants' and Students' Interaction and Skill Development in Clinical Practice.] Studentlitteratur, Lund.

[30] Astvik, W. (2003) Relationer som Arbete: Förutsättningar för Omsorgsfulla Möten i Hemtjänsten. [Relations as Work: Conditions for Diligent Meetings in Home Care.] Arbete och Hälsa, 8, 1-72.

[31] Josefson, I. (1991) Kunskapens Former: Det Reflekterande Yrkeskunnandet. [The Forms of Knowledge: The Reflective Professionalism.] Carlssons Bokförlag, Stockholm.

[32] Salthouse, T. (1996) The Processing-Speed Theory of Adult Age Differences in Cognition. Psychological Review, 103, 403-428. https://doi.org/10.1037/0033-295X.103.3.403

[33] Salthouse, T. (2000) Aging and Measures of Processing Speed. Biological Psycholo$g y$, 54, 35-54. https://doi.org/10.1016/S0301-0511(00)00052-1

[34] Mather, M. (2010) Aging and Cognition. Cognitive Science, 1, 346-362. https://doi.org/10.1002/wcs.64

[35] Barnes, L.B., Christensen, C.R. and Hansen, A. (1994) Teaching and the Case Method. Harvard Business School Press, Boston.

[36] Klepke, B., Lothigius, J. and Roxström, C. (2002) Gränslöst Lärande i Lund: Drivkraft om Konsten Att Förändra pa Jobbet. [Borderless Learning in Lund: Driving Forces in the Art to Change Work.] Landstingsförbundet, Stockholm.

[37] Tärnvik, A. (2004) Case-Metodik-Undervisningsform som Engagerar. [Case Method-A Form of Teaching that Engages.] Läkartidningen, 43, 3314-3319.

[38] Kjellén, B., Lundberg, K. and Myrman, Y. (2004) Att Skriva Case: En Handbok om att Undervisa och att Skriva. [To Write Cases: A Handbook in Teaching and Writing.] Network for Case Methods Learning, Council for the Renewal of Higher Education, Gothenburg.

[39] Neuman, W.L. and Kreuger, L.W. (2003) Social Work Research Methods. Allyn \& Bacon, Boston.

[40] Lindgren, G. (1999) Klass, Kön och Kirurgi: Relationer bland Vardpersonal i Organisationsförändringarnas Spar. [Class, Gender and Surgery: Relations between Health Care Workers in the Traces of Organisational Changes.] Liber, Malmö.

[41] Silfverberg, G. (2005) Praktisk Klokhet-Om Dialogens och Dygdens Betydelse för Yrkesskicklighet och Socialpolitik. [Practical Wisdom-About the Significance of 
Dialogue and Virtue in Workmanship and Social Politics.] Fou Skanes Skriftserie, Lund.

Submit or recommend next manuscript to SCIRP and we will provide best service for you:

Accepting pre-submission inquiries through Email, Facebook, LinkedIn, Twitter, etc. A wide selection of journals (inclusive of 9 subjects, more than 200 journals)

Providing 24-hour high-quality service

User-friendly online submission system

Fair and swift peer-review system

Efficient typesetting and proofreading procedure

Display of the result of downloads and visits, as well as the number of cited articles Maximum dissemination of your research work

Submit your manuscript at: http://papersubmission.scirp.org/

Or contact jss@scirp.org 